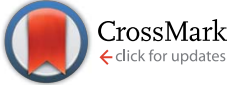

Cite this: RSC Adv., 2016, 6, 95044

\title{
Potential of hybrid iron oxide-gold nanoparticles as thermal triggers for pancreatic cancer therapy
}

\author{
Adeolu Oluwasanmi, ${ }^{a}$ Maryam Malekigorji, ${ }^{\text {a }}$ Stefanie Jones, ${ }^{b}$ Anthony Curtis $^{a}$ \\ and Clare Hoskins ${ }^{\star a}$
}

Theranostics are emerging platforms for rapid cancer diagnosis and therapy. Hybrid iron oxide-gold nanoparticles (HNPs) have shown potential as theranostics due to their ability for imaging using MRI, heating using laser irradiation and carrier abilities for drug molecules after surface functionalization. The ability of HNPs to act as localised nano-heaters has been well documented for tumour ablation applications where maximal heating effect is desired. However, the use of HNPs as thermal triggers for drug release requires more control over temperature output and careful consideration of heat dissipation. In this work we report the potential of HNPs to act as localised nano-heaters in vitro and document the cellular effect prior and post laser irradiation in human pancreatic adenocarcinoma (BxPC-3) cell lines. The data showed that after incubation of $50 \mu \mathrm{g} \mathrm{mL}^{-1} \mathrm{HNPs}$, a thermal increase of up to $9{ }^{\circ} \mathrm{C}$ was observed in the cells after laser irradiation with the total area experiencing heat dissipation from the laser beam being $346 \mathrm{~mm}^{2}$. Although the total temperature experienced by cells was below the perceived temperature for irreversible cell damage, after $24 \mathrm{~h}$ significant levels of HSP27 and HSP70 were evident with a drop in cell viability to $85 \%$. This indicated that even with rapid irradiation at low temperatures the cells were undergoing stress. Upon I.T. injection in pancreatic xenograft models, a similar heating capacity was observed at identical concentration which also resulted in bulk tumour dissipation. The findings from this work highlight the factors which must be taken into consideration when designing HNPs as theranostics for heat triggered drug delivery.

Received 15th August 2016

Accepted 28th September 2016

DOI: 10.1039/c6ra20552f

www.rsc.org/advances to attain a therapeutic effect. As a result, patients experience a greater degree and extent of side effects such as increased risk of infection, bruising and bleeding, anaemia, nausea, breathlessness, renal or hepatic impairment, hair loss and tiredness. ${ }^{5}$ These side effects result from the systemic circulation of the toxic drug agents and their lack of specificity. Nanotechnology is increasingly being exploited for use in cancer therapy with formulations such as Abraxane ${ }^{\circledR}$ and Onivyde ${ }^{\circ}$ gaining regulatory approval in the last five years. ${ }^{6}$ The use of nanotechnology is favoured in cancer therapy due to the unique properties of particulates at this size range, ${ }^{7}$ diversity of architecture and compositions, ${ }^{8}$ ease of synthesis ${ }^{9}$ and their ability to passively target cancerous vasculature resulting in deeper tissue permeation via the enhanced permeability and retention effect. ${ }^{10}$ Advances in nanotechnology for cancer therapy has led to the development of multifunctional entities known as theranostics.

Theranostics are platforms which offer simultaneous diagnosis and therapy, resulting in decreased treatment times. ${ }^{11}$ These theranostic agents allow for real time imaging after administration, enabling location mapping before initiating therapeutic effect (e.g. ablation/drug release/combination). By coupling treatments to diagnostics and controlling drug release, a rapid and localised clinical effect can be achieved. Early diagnosis in disease states such as pancreatic cancer can
Institute for Science and Technology in Medicine, School of Pharmacy, Keele University, Keele, ST5 5BG, UK. E-mail: c.hoskins@keele.ac.uk; Tel: +44 (0)1782 734799

${ }^{b}$ School of Life Sciences, Faculty of Natural Sciences, Keele University, Keele, ST5 5BG, $U K$ 
mean the difference between life and death. Many types of theranostics have been reported using both organic and inorganic nanoparticulates. ${ }^{12}$ One class of theranostic agents which has shown potential due to its chemical and physical stability, ease of synthesis and scope for further functionalisation are hybrid nanoparticles. ${ }^{13}$

Hybrid nanoparticles consisting of an iron oxide core surrounded by a gold shell have shown great promise in cancer therapy. ${ }^{14}$ Their ability to act as $T_{2}$ contrast agents for MRI imaging arising from their magnetic iron oxide core and to act as both nano-heaters ${ }^{\mathbf{1 5}}$ and drug carriers after surface functionalisation of the gold shell has been reported previously. ${ }^{\mathbf{1 4 , 1 6}}$ The use of HNPs as carriers for anticancer agents attached onto the gold surface via linker molecules or with the exploitation of thiol-gold chemistry has been reported..$^{\mathbf{1 4 1 6}}$ Wagstaff et al. reported the conjugation of cisplatin onto the surface of HNPs. ${ }^{15}$ The cisplatin was conjugated through a thiolated polyethylene glycol (PEG) linker. The HNPs produced showed low inherent cytotoxicity on ovarian cancer cell lines (A2780 and A2780/cp70), however the cisplatin conjugated HNPs exhibited up to a 110fold more cytotoxic effect than the free drug. ${ }^{16}$ Other studies have been focused on the use of HNPs as drug carriers for pancreatic cancer therapy. Barnett et al. studied the attachment of cytotoxic agent 6-thioguanine (6-TG) onto HNPs. ${ }^{14}$ In this study, the HNP-6-TG formulation exhibited a 10-fold decrease $\mathrm{IC}_{50}$ in comparison with the free drug in human pancreatic adenocarcinoma (BxPC-3 cells). ${ }^{\mathbf{1 4}}$

Colloidal gold undergoes surface plasmon resonance (SPR) when irradiated with light of a specific wavelength resulting in the rapid conversion of absorbed light into heat energy. ${ }^{17}$ The absorbed light energy is rapidly transformed into thermal energy due to the delocalised electrons in the gold shell promoting an increase in temperature; in effect, acting as a localised heating source. ${ }^{18}$ Hence these HNPs possess the potential to act as nano-heaters for tumour ablation or stimuli responsive drug release.

Studies have highlighted the use of HNPs in thermal ablation of pancreatic cancer. Guo et al. reported cell viability reduction as high as $97.7 \%, 24 \mathrm{~h}$ after irradiation of GoldMag ${ }^{\circledR}$ particles incubated inside human pancreatic (PANC-1) cells. ${ }^{19}$ Other work has reported the advantages of dual heating HNPs through both laser irradiation and magnetic hyperthermia. ${ }^{20}$ Espinosa et al. documented the amplification of heating experienced by the HNPs was 15 -fold compared with magnetic stimulation only for tumour ablation application. This was tested both in vitro in SKOV3, PC3, and A431 cells lines and in vivo in xenograft skin cancer models. ${ }^{20}$

The use of HNPs for thermo-responsive drug delivery is now a major focus. This technology benefits from magnetic properties, reduced toxicities and the ability to target the drug release using focused laser irradiation. Previously we reported the controllable heating capacity and resultant dissipation after irradiation of HNPs in agar phantoms at varied concentrations. ${ }^{21}$ These studies suggested that the HNPs used $(50 \mathrm{~nm})$ would be useful for stimuli responsive drug release as their heating could be controlled via alteration of irradiation time and concentration. In order for HNPs to be used to thermally trigger drug release it is important that their temperature rise is not sufficient to cause any thermal degradation of drug or widespread heat dissipation at high temperatures which would affect healthy tissue. As such, for use as a drug carrier and not an ablation agent, it is important that only localised heating is experienced and that any temperatures experienced are not high enough to dissipate away from the tumour site causing unnecessary damage. It is postulated that use of HNPs, which heat up (the bulk) to a maximal temperature below the temperature at which irreversible damage is caused to the cells which is approximately $50{ }^{\circ} \mathrm{C}$, will result in a system that will be most effective.

Studies on the thermal potential and heat dissipation of HNPs for stimuli responsive drug delivery have been reported, however the majority of these have been either been carried out using computer modelling ${ }^{22}$ or in the use of agar phantoms ${ }^{21,23}$ and little studies have shown heating abilities after cellular internalization. Whilst gel phantoms are designed to mimic physiological tissue there is an increasing need to fully understand the heating ability and effect on surroundings experienced after irradiation in more realistic conditions either in vitro or in vivo.

In this study the potential of HNPs to act as thermal triggers for drug release is evaluated in vitro using human pancreatic adenocarcinoma cells. The rate of thermal increase and heat dissipation away from the irradiation site will be investigated as well as the effect of HNPs on cells prior to and post irradiation. Additionally the heating effect in solid pancreatic tumours will be mapped post mortem after intratumoural administration in xenograft models.

\section{Experimental}

\subsection{Materials}

All chemicals unless otherwise stated were purchased from Sigma Aldrich (UK) and all solvents from Fisher Scientific (UK).

\subsection{Imaging of HNPs using transmission electron microscopy}

HNP suspensions ( $50 \mu \mathrm{g} \mathrm{mL} \mathrm{m}^{-1}, 2 \mu \mathrm{L}$ ) were dried onto formvar coated copper grids. The grids were imaged using a JEOL JEM1230 microscope (Jeol, Japan) using anaLYSIS software.

\subsection{Quantification of cellular uptake of HNPs in BxPC-3 cells}

BxPC-3 cells were seeded into 6-well plates (50 000 cells per well) and incubated at $37{ }^{\circ} \mathrm{C}$ with $5 \% \mathrm{CO}_{2}$. HNPs $\left(5 \mu \mathrm{g} \mathrm{mL}{ }^{-1} \& 50 \mu \mathrm{g}\right.$ $\mathrm{mL}^{-1}$ ) were incubated with the cells for $24 \mathrm{~h}$. Cells were washed with phosphate buffered saline (PBS) four times and trypsinised. Cells were resuspended (1000 $\left.000 \mathrm{~mL}^{-1}\right)$ in fresh RPMI media supplemented with $10 \%$ foetal bovine serum and $1 \%$ penicillin streptomycin (Thermofisher, UK). The cell suspension $(1 \mathrm{~mL})$ was placed into an Eppendorf tube and centrifuged at $1000 \mathrm{rpm}$ for $10 \mathrm{~min}$. The supernatant was discarded and the cells were resuspended in $1 \mathrm{~mL}$ of concentrated nitric acid. The solutions were incubated at $90{ }^{\circ} \mathrm{C}$ for $1 \mathrm{~h}$ before dilution in deionised water. The iron (Fe) content was determined using 
inductively coupled plasma-optical emission spectroscopy (ICPOES), compared against a calibration of known standards $\left(R^{2}=\right.$ 0.999 ) and the amount of iron internalised was calculated per cell.

\subsection{Imaging cellular uptake of HNPs using transmission electron microscopy}

Cellular internalisation images were taken after incubation of HNPs with BxPC-3 cells. Cells were grown onto Aclar slides and incubated with HNP $\left(5 \mu \mathrm{g} \mathrm{mL} \mathrm{m}^{-1} \& 50 \mu \mathrm{g} \mathrm{mL} \mathrm{m}^{-1}\right)$ for $24 \mathrm{~h}$. Cells were washed with PBS and fixed with $2.5 \%$ glutaraldehyde in 0.1 M sodium cacodylate buffer : $2 \mathrm{mM}$ calcium chloride $(50: 50)$ for $2 \mathrm{~h}$. The samples were washed for $5 \mathrm{~min}$ in $0.1 \mathrm{M}$ sodium cacodylate buffer : $2 \mathrm{mM}$ calcium chloride and this step was repeated a three times. The samples were post fixed in $0.1 \%$ osmium tetroxide in $0.1 \mathrm{M}$ sodium cacodylate buffer $/ 2 \mathrm{mM}$ calcium chloride for $1 \mathrm{~h}$. A dehydration series was carried out using ethanol before the samples were embedded in spurr resin. The samples were sectioned using a freshly cut diamond knife and placed onto formvar coated copper grids for imaging. The samples were imaged using a JEOL JEM-1230 microscope (Jeol, Japan) using anaLYSIS software.

\subsection{Cellular response to HNP exposure using BxPC-3 cells}

2.5.1 Cell membrane integrity. Membrane integrity was measured via quantification of lactate dehydrogenase (LDH) leakage using a CytoTox-ONE ${ }^{\mathrm{TM}}$ assay (Promega, UK) on BxPC-3 cells. Cells were seeded into 6-well plates (50 000 cells per well) and incubated for $24 \mathrm{~h}$. HNPs were incubated with cells (5-500 $\mu \mathrm{g} \mathrm{mL}{ }^{-1}$ ) for $1,24,48 \& 72 \mathrm{~h}$ at $37{ }^{\circ} \mathrm{C}$ and $5 \% \mathrm{CO}_{2}$. After incubation, $2 \mu \mathrm{L}$ of lysis buffer was added to the positive control wells, and the plate was centrifuged at $1500 \mathrm{rpm}$ for $10 \mathrm{~min}$ at 37 ${ }^{\circ} \mathrm{C}$. After centrifugation, $50 \mu \mathrm{L}$ of the supernatant was removed from each well and placed into a new plate, and $50 \mu \mathrm{L}$ of a membrane integrity assay reagent was added to the wells. The plates were incubated for $10 \mathrm{~min}$ at $37{ }^{\circ} \mathrm{C}$ in the dark. Stop reagent $(25 \mu \mathrm{L})$ was added to the wells, and the $\mathrm{LDH}$ levels were recorded at excitation wavelength $560 \mathrm{~nm}$ \& emission wavelength $590 \mathrm{~nm}$, using a Tecan Pro200 microplate reader (Tecan, UK). The percentage of cytotoxicity was calculated in respect to control wells containing no nanoparticles.

2.5.2 Cell viability. BxPC-3 cells were seeded into 6-well plates (50 000 cells per well) and incubated for $24 \mathrm{~h}$. HNPs were incubated with cells $\left(5-500 \mu \mathrm{g} \mathrm{mL}{ }^{-1}\right)$ for $1,24,48 \& 72 \mathrm{~h}$ at $37^{\circ} \mathrm{C}$ and $5 \% \mathrm{CO}_{2}$. Cells were washed with PBS and trypsinised and resuspended in $1 \mathrm{~mL}$ fresh media. Cell suspension $(50 \mu \mathrm{L})$ was mixed with $50 \mu \mathrm{L}$ trypan blue solution for $1 \mathrm{~min}$. Cells were counted using a Countess ${ }^{\circledR}$ automated cell counter (Thermofisher, UK). Cell viability was determined in respect to control cells with no nanoparticles present.

\subsection{Investigation into heat generation and dissipation of HNPs in vitro}

BxPC-3 cells were seeded into 6-well plates (50 000 cells per well) containing quartz coverslips (Alfa Aesar, USA) and incubated at $37{ }^{\circ} \mathrm{C}$ with $5 \% \mathrm{CO}_{2}$. HNPs $\left(5 \mu \mathrm{g} \mathrm{mL}^{-1} \& 50 \mu \mathrm{g} \mathrm{mL}{ }^{-1}\right)$ were incubated with the cells for $24 \mathrm{~h}$. The cells were washed with phosphate buffered saline (PBS) four times and the coverslips were removed from the plate. The cells were irradiated at 1064 nm using a ML-LASER-YB5 Q-switched Nd:YAG Laser Treatment System (WeiFang MingLiang Electronics Company Ltd., China). Pulse width: $10 \mathrm{~ns}$, pulse repetition frequency: $6 \mathrm{~Hz}$, laser spot diameter: $3 \mathrm{~mm}$, cooling system: water cooled with airflow cooling. The beam was collimated through concave lenses to a 1 mm diameter and passed through the cell sample. The cells were irradiated for 60 seconds and their changing temperature $(\Delta T)$ was monitored using Optris PI640 Thermal Imaging Camera (Optris, Germany). The camera was positioned $5 \mathrm{~cm}$ away from the cells and focussed on the irradiation site. The data was recorded on Optris PI Connect software (Optris, Germany). Data samples were recorded every 0.1 second and data analysis was carried out offline using direct measurement of the .vga files collected. The $\Delta T$ was calculated as per eqn (1):

$$
\Delta T=\left(T_{\text {final }}-T_{\text {initial }}\right)-T_{\Delta \text { control }}
$$

Heat dissipation of the samples was measured using pixel analysis offline with optical resolution of $640 \times 480$ pixel. Effect of multiple irradiation cycles on cellular heating was investigated using 60 seconds irradiation and 60 second cooling cycles repeated over 600 seconds and monitored as above.

\subsection{Measurement of heat shock protein production after laser irradiation}

BxPC-3 cells were seeded into a quartz 96-well plate (Alfa Aesar, USA) (15 000 cells per well) and incubated at $37^{\circ} \mathrm{C}$ with $5 \% \mathrm{CO}_{2}$. HNPs $\left(5 \mu \mathrm{g} \mathrm{mL}{ }^{-1} \& 50 \mu \mathrm{g} \mathrm{mL}^{-1}\right)$ were incubated with the cells for $24 \mathrm{~h}$. Cells were washed with phosphate buffered saline (PBS) four times and the liquid aspirated from the wells. The cells were irradiated at $1064 \mathrm{~nm}$ as previously described for 60 seconds. After irradiation fresh cell culture medium $(100 \mu \mathrm{L})$ was placed into the wells and the plate was incubated for $24 \mathrm{~h}$.

2.7.1 HSP27. Heat shock protein 27 (HSP27 (total)) production was measured using an ELISA kit (Thermofisher, UK). Briefly, $50 \mu \mathrm{L}$ of standards and samples (cell lysates) were added to the 96-well immunoassay plate along with $50 \mu \mathrm{L} \mathrm{Hu}$ HSP (total) detection antibody. The plate was incubated at room temperature for $2 \mathrm{~h}$. After this time the wells were washed four times with wash buffer. Anti-rabbit IgG HRP $(100 \mu \mathrm{L})$ was added to the wells and the plate incubated for $0.5 \mathrm{~h}$ at room temperature. The plate was washed with buffer a further four times before $100 \mu \mathrm{L}$ stabilized chromogen was added to the wells. The plate was incubated at room temperature in the dark for $0.5 \mathrm{~h}$ after which time $100 \mu \mathrm{L}$ of stop solution was added to each well. The absorbance of each well was measured at $450 \mathrm{~nm}$ using a Tecan Pro200 microplate reader (Tecan, UK). The levels of HSP27 produced in the irradiated cells was calculated in respect to control cells with no nanoparticles.

2.7.2 HSP70. Heat shock protein 70 (HSP70) production was measured using an ELISA kit (Enzo, USA). Briefly, $100 \mu \mathrm{L}$ of standards and samples (cell lysates) were added to the 96-well immunoassay plate along with $50 \mu \mathrm{L} \mathrm{Hu} \mathrm{HSP} \mathrm{(total)} \mathrm{detection}$ antibody. The plate was incubated at room temperature for $2 \mathrm{~h}$. 
After this time the wells were washed four times with wash buffer. HSP70 antibody $(100 \mu \mathrm{L})$ was added to the wells and the plate incubated for $1 \mathrm{~h}$ at room temperature. The plate was washed with buffer a further four times before $100 \mu \mathrm{L}$ HSP70 conjugate was added to the wells. The plate was incubated at room temperature for $1 \mathrm{~h}$ after which time the wells were washed a further four times with wash buffer. TMB substrate $(100 \mu \mathrm{L})$ was added to the wells and incubated for $0.5 \mathrm{~h}$ before addition of $100 \mu \mathrm{L}$ of stop solution. The absorbance of each well was measured at $450 \mathrm{~nm}$ using a Tecan Pro200 microplate reader (Tecan, UK). The levels of HSP70 produced in the irradiated cells was calculated in respect to control cells with no nanoparticles.

\subsection{Cytotoxicity after laser irradiation}

BxPC-3 cells were seeded into 6-well plates (50 000 cells per well) containing quartz coverslips (Alfa Aesar, USA) and incubated at $37{ }^{\circ} \mathrm{C}$ with $5 \% \mathrm{CO}_{2}$. HNPs $\left(5 \mu \mathrm{g} \mathrm{mL}{ }^{-1} \& 50 \mu \mathrm{g} \mathrm{mL}{ }^{-1}\right)$ were incubated with the cells for $24 \mathrm{~h}$. Cells were washed with phosphate buffered saline (PBS) four times. The coverslips were removed from the wells and cells were irradiated at $1064 \mathrm{~nm}$ as previously described (60 seconds and multiple irradiation cycles). After irradiation the coverslips were placed back into the wells and fresh media was added and the cells were incubated for $24 \mathrm{~h}$. After this time the cytotoxicity was measured using trypan blue exclusion as previously described. Cytotoxicity was measured in relation to control cells with no nanoparticles.

\subsection{Detection of apoptosis via measurement of caspase-3 activity after laser irradiation}

BxPC-3 cells were seeded into 6-well plates (50 000 cells per well) containing quartz coverslips (Alfa Aesar, USA) and incubated at $37{ }^{\circ} \mathrm{C}$ with $5 \% \mathrm{CO}_{2}$. HNPs $\left(5 \mu \mathrm{g} \mathrm{mL} \mathrm{mL}^{-1} \& \mu \mathrm{g} \mathrm{mL}^{-1}\right)$ were incubated with the cells for $24 \mathrm{~h}$. Cells were washed with phosphate buffered saline (PBS) four times. The coverslips were removed from the wells and cells were irradiated at $1064 \mathrm{~nm}$ as previously described (60 seconds and multiple irradiation cycles). After irradiation the coverslips were placed into the 6-well plate and fresh media was added. The cells were incubated for $24 \mathrm{~h}$. After this time the level of apoptosis was measured using a caspase-3 assay. After $24 \mathrm{~h}$, the supernatant was removed and detached using trypsin. The cell suspensions were centrifuged for 10 minutes at $250 \mathrm{~g}$. The supernatant was removed and $25 \mu \mathrm{L}$ of cold lysis buffer was added to the cell pellet. Caspase- 3 substrate $(5 \mu \mathrm{L}$, Ac-DEVD-pNA) was added to the samples before transferring to a 96-well plate. The plate was incubated at $37{ }^{\circ} \mathrm{C}$ for $1 \mathrm{~h}$ before absorbance measurement at $405 \mathrm{~nm}$. Apoptosis levels were measured in relation to control cells with no nanoparticles.

\subsection{Imaging of cellular topography after laser irradiation using atomic force microscopy}

BxPC-3 cells were seeded into 6-well plates (50 000 cells per well) containing quartz coverslips (Alfa Aesar, USA) and incubated at $37{ }^{\circ} \mathrm{C}$ with $5 \% \mathrm{CO}_{2}$. HNPs $\left(5 \mu \mathrm{g} \mathrm{mL}{ }^{-1} \& 50 \mu \mathrm{g} \mathrm{mL}{ }^{-1}\right)$ were incubated with the cells for $24 \mathrm{~h}$. Cells were washed with phosphate buffered saline (PBS) four times and the coverslips removed from the plate. The cells were irradiated at $1064 \mathrm{~nm}$ as previously described. After irradiation the coverslips were returned to the 6-well plates and fresh media was added. The cells were incubated for $24 \mathrm{~h}$. After this time the media was removed and cells washed four times with PBS. The cells were fixed using $2.5 \%$ glutaraldehyde in PBS for $10 \mathrm{~min}$. Fixed cells were washed five times with PBS and mounted on glass slides. Cell topography was imaged using a Bruker Catalyst Atomic Force Microscope (Bruker, Germany) using Scan Asyst Adaptive Mode. Cell membrane topography was imaged using a Scan Asyst in Air tip of spring constant $0.4 \mathrm{~N} \mathrm{~m}^{-1}$, carrying out 896 scans per line at a scan rate of $0.32 \mathrm{~Hz}$ and $1.102 \mathrm{~V}$ amplitude.

Cell membrane roughness was measured using the topography images with Nanoscope Analysis software (Bruker, Germany). Small areas $(1000 \times 1000 \mathrm{~nm})$ were chosen at random on ten areas of each cell and their membrane roughness determined. An average was calculated from a total of thirty areas from three cells.

\subsection{In situ measurement and imaging of tumour heating in pancreatic xenograft models}

Female $\mathrm{Nu} / \mathrm{Nu}$ mice, five weeks of age $(n=3)$, (Charles River, UK) were kept in pathogen-free conditions (weight of mice was 20-25 g). All procedures and animal care were carried out according to Project License PPL 70/8806 granted by the UK Home Office. Human pancreatic cancer cell line BxPC-3 was cultured to $90 \%$ confluence in RPMI 1640 supplemented with $10 \%$ fetal bovine serum and $1 \%$ penicillin streptomycin. The cells were washed twice with cold PBS and harvested with trypsin for $10 \mathrm{~min}$ at $37^{\circ} \mathrm{C}$. The cells were washed three times with PBS and resuspended in 50:50 media : PBS. The tumour cell suspension $\left(3.0 \times 10^{6}\right.$ cells in $100 \mu \mathrm{L}$ of $50: 50$ PBS : media) was injected subcutaneously (s.c.) in the right flank of each mouse. When the tumour became palpable (approximately after one week), measurements in two dimensions with vernier calipers were carried out twice a week and volume tumours calculated according to eqn (2).

$$
V=4 / 3 \pi\left[\left(D_{1}+D_{2}\right) / 4\right]^{3}
$$

Once tumour volume reached a maximum of $0.9 \mathrm{~cm}^{3}$ the mice were sacrificed and used for imaging immediately post mortem. HNP solution $\left(0.2 \mathrm{mg} \mathrm{kg}^{-1}, 100 \mu \mathrm{L}\right)$ was injected intratumorally (I.T.) using a 26 gauge needle (Vet-Tech, UK). The tumour was irradiated at $1064 \mathrm{~nm}$ as previously described for 60 seconds and temperature change \& heat dissipation measured using an Optris PI640 Thermal Imaging Camera (Optris, Germany). The $\Delta T$ data was calculated in relation to a tumour bearing mouse after irradiation with no nanoparticles (only PBS) injected I.T. as per eqn (1).

\section{Results and discussion}

\subsection{Imaging of HNPs using transmission electron microscopy}

In this work HNPs composed of an iron oxide core surrounded by a gold shell with attached PEG were used. The HNPs were 
A
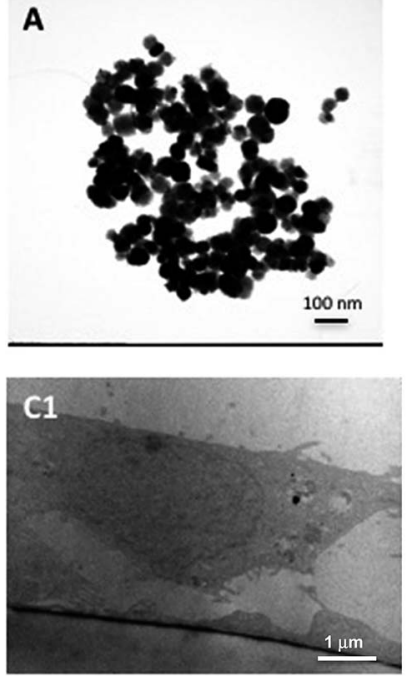

B
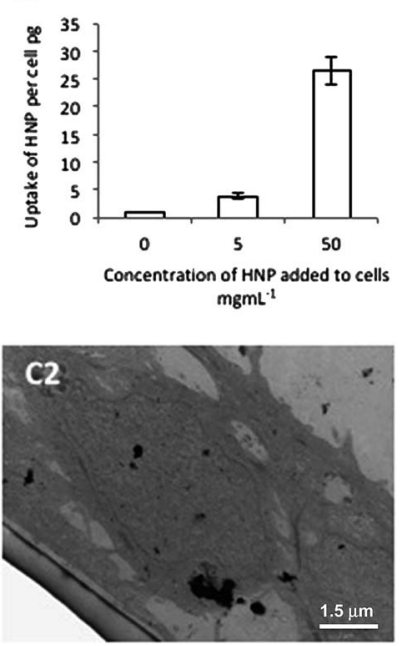

Fig. 1 Characterisation of HNPs (A) size and morphology carried out using transmission electron microscopy (TEM) \& cellular uptake in BxPC-3 cells after $24 \mathrm{~h}$ incubation carried out using (B) inductively coupled plasma-optical emission spectroscopy ( $n=3 \pm$ SD) and (C) TEM after incubation with $5 \mu \mathrm{g} \mathrm{mL}^{-1}$ and $50 \mu \mathrm{g} \mathrm{mL}^{-1}$.

spherical in shape and $50 \mathrm{~nm}( \pm 5 \mathrm{~nm}, n=25)$ as observed using TEM (Fig. 1A). The synthetic pathway was monitored using zeta potential measurement, UV-Vis spectrometry and the mass composition ratio of the HNPs was quantified by inductively coupled plasma-optical emission spectroscopy and calculated to be $1: 0.3: 0.16$ (Fe : Au : PEG) as previously described. ${ }^{13}$ All subsequent concentrations quoted will be based on Fe content of the HNPs.

\subsection{Cellular uptake of HNPs into BxPC-3 cells}

The nanoparticles were incubated with BxPC-3 cells and their cellular uptake measured using ICP-OES. Here the Fe content of the cells was representative of HNP uptake and compared with the physiologically present Fe in control cells. Fig. 1B shows that cellular uptake of the HNPs was concentration dependent with the $50 \mu \mathrm{g} \mathrm{mL}{ }^{-1}$ sample internalizing 6.9-fold more Fe per cell than the $5 \mu \mathrm{g} \mathrm{mL}{ }^{-1}$ sample. These findings were in agreement with the TEM images showing HNP uptake (Fig. 1C1 and 2) where more HNPs were observed in the cells incubated with higher concentrations.

\subsection{Cellular response to HNP exposure}

In order for HNPs to be a clinically viable platform for theranostics or drug carriers, they must themselves be relatively noncytotoxic. In order to investigate the cellular response after exposure and internalization of these particles the cell membrane integrity and cytotoxicity was measured over a $72 \mathrm{~h}$ period. Cell membrane integrity was estimated via quantification of $\mathrm{LDH}$ release from cells. The data showed that over the $72 \mathrm{~h}$ study no significant release of $\mathrm{LDH}$ was detected in comparison to the untreated control cells up to $500 \mu \mathrm{g} \mathrm{mL} \mathrm{m}^{-1}$ (Fig. 2A). This suggested that the cell membrane had not been compromised upon exposure to the nanoparticles and that nanoparticle uptake was not driven by membrane permeation. It is reported that for the majority of nanoparticles, uptake is driven by endocytosis. $^{24-26}$ In this work endocytosis is the most likely uptake mechanism as the TEM image (Fig. 1C2) shows nanoparticle accumulation inside what appears to be an endosome under formation. This finding is in agreement with previous more in depth studies regarding cellular uptake of similar HNP structures. ${ }^{13}$

Cell viability was measured using trypan blue exclusion where a live/dead cell count was measured (Fig. 2B). This study indicated that cytotoxicity was both time and concentration dependent. The data suggested that up to concentrations of 100 $\mu \mathrm{g} \mathrm{mL}^{-1}$ no significant reduction on cell viability was experienced up to $48 \mathrm{~h}$ ( $p>0.01$ although at $72 \mathrm{~h}$ a non-significant reduction was evident above $25 \mu \mathrm{g} \mathrm{mL}{ }^{-1}$ ). At the highest concentration tested $\left(500 \mu \mathrm{g} \mathrm{mL} \mathrm{m}^{-1}\right)$ a significant decrease in cell viability was observed after only $1 \mathrm{~h}$ with $80 \%$ cell viability $(p<$ 0.01 ), however, the viability did not further decrease over time. Both the cell membrane integrity and the cytotoxicity studies indicated that at $5 \mu \mathrm{g} \mathrm{mL}{ }^{-1}$ and $50 \mu \mathrm{g} \mathrm{mL}{ }^{-1}$, no significant adverse effect to the cells would be experienced due to the presence or internalization of the HNPs.

\subsection{Investigation into heat generation and dissipation of HNPs in vitro}

Evaluation into the extent of thermal rise experienced in vitro after irradiation of HNPs inside BxPC-3 cells was carried out. The measurements theoretically should give a better indication of potential of the HNPs to act as nano-heaters in biomedicine compared with studies carried out in phantoms. The cells were grown on quartz to ensure no heating effect was experienced due to laser absorption of the coverslips, which would have occurred with glass. The cells were then incubated with HNPs of $5 \mu \mathrm{g} \mathrm{mL} \mathrm{m}^{-1} \& 50 \mu \mathrm{g} \mathrm{mL} \mathrm{m}^{-1}$ for $24 \mathrm{~h}$ to mimic the cellular uptake quantifications studies. The cells were irradiated using $1064 \mathrm{~nm}$ laser light, as previously described ${ }^{\mathbf{1 3}}$ the UV-Vis absorbance for these particles is very broad with a $\lambda_{\max }$ of $670 \mathrm{~nm}$. However, irradiation is achievable at $1064 \mathrm{~nm}$ due to this broad absorbance. Pulsed laser systems operating at $1064 \mathrm{~nm}$ are commonly utilized in the cosmetics and ophthalmic industries and hence these systems are reliable and relatively inexpensive. This is an important factor in the translation of such therapies into the clinic. After irradiation, our data showed that at the lower incubation concentration $\left(5 \mu \mathrm{g} \mathrm{mL}{ }^{-1}\right)$, no major heating effect was experienced with a $\Delta T$ of $0.5{ }^{\circ} \mathrm{C}$ after 60 seconds (Fig. 3A). However, at the higher concentration of $50 \mu \mathrm{g} \mathrm{mL}$ the HNPs did experience localised heating resulting in a bulk $\Delta T$ of approximately $9{ }^{\circ} \mathrm{C}$ after the full irradiation time. In contrast to previous work using HNPs suspended in agar phantoms, the thermal rise profile looked remarkably different. ${ }^{21}$ Previously we found that the HNPs heated up rapidly reaching their maximum temperature $\left(40{ }^{\circ} \mathrm{C}, 50 \mu \mathrm{g} \mathrm{mL}{ }^{-1}\right)$ within the first 10 seconds after which a plateau was reached. However, in this study the HNPs appeared to undergo a continual heating profile with their maximum achievable 

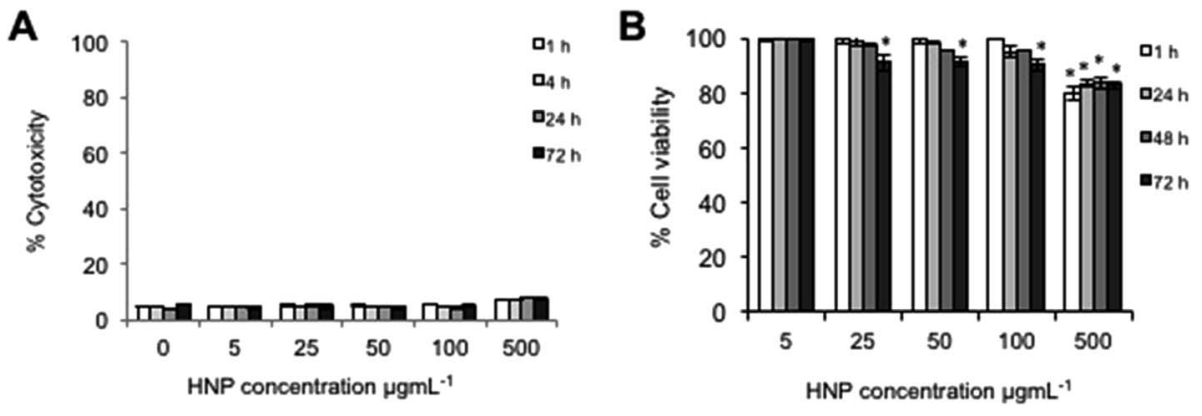

Fig. 2 Cellular response of BxPC-3 cells after incubation with HNPs $\left(0-500 \mu \mathrm{g} \mathrm{mL}^{-1}\right)$ over $72 \mathrm{~h}$. (A) Cell membrane integrity measured via lactate dehydrogenase level \& (B) cytotoxicity measured by trypan blue exclusion. All data quoted in relation to control cells $(n=3 \pm$ SD). $*$ denotes significant reduction in viability compared with control sample $(p<0.01)$.

temperature being more than 4 -fold less reached after the full 60 seconds of irradiation. This could be due to the fact that the concentrations used in this study are much reduced (not all HNPs incubated become internalised and some will be washed away), by the fact that they are existing in a different, more complex media (presence salts, pH's etc.) or that the heat capacity and ability to dissipate heat inside cells differs from the agar phantoms. In fact, when looking at the cellular uptake study, the concentration of Fe internalised after incubation with $50 \mu \mathrm{g} \mathrm{mL} \mathrm{m}^{-1}$ was approximately $26 \mathrm{pg}$ per cell. Looking at the lower concentration incubation $\left(5 \mu \mathrm{g} \mathrm{mL}{ }^{-1}\right)$, the uptake achieved was approximately $5 \mathrm{pg}$ per cell. This shows that there is a non-linear relationship in the cell internalisation of the particles. After internalisation the cells were estimated to be in the magnitude of $10^{6}$ in the wells. Hence, it appears that the majority of the HNPs were internalised at the lower concentration incubation. However, at the higher concentration, approximately $50 \%$ of total HNPs have been internalised, this is probably the major factor in the difference between phantom and in vitro thermal rise temperatures.

The heat dissipation from the laser focal point was determined after 60 seconds irradiation. Fig. 3B shows the heat dissipation profile for $50 \mu \mathrm{g} \mathrm{mL}{ }^{-1}$ HNPs incubated in the cells, where a thermal rise was observed after 60 seconds irradiation as far as $10 \mathrm{~mm}$ either side of the irradiation point, thus making the total area experiencing a thermal increase $346 \mathrm{~mm}^{2}$. Interestingly, in the phantom studies the heat dissipation at $50 \mu \mathrm{g}$ $\mathrm{mL}^{-1}$ was detectable using an identical measurement technique at distances only up to $6 \mathrm{~mm}$ away from the irradiation point with a total area thermally effected of only $133 \mathrm{~mm}^{2}$. The increase in heat dissipation shown in the in vitro experiments may give rise to the exponential $\Delta T$ profile of Fig. 3A. If the irradiation area is dissipating the heat to a greater surrounding area then the HNPs may be losing heat more rapidly and the
A

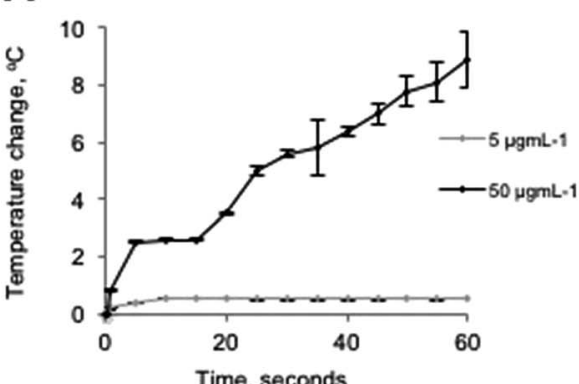

B

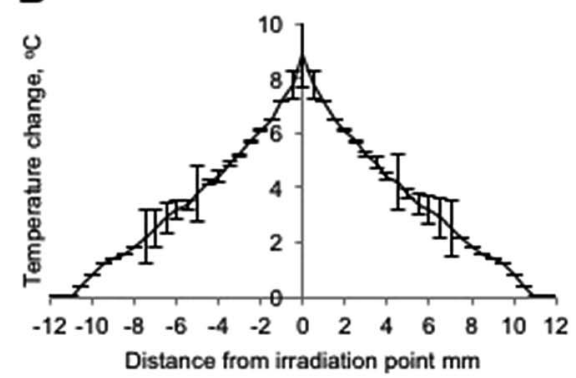

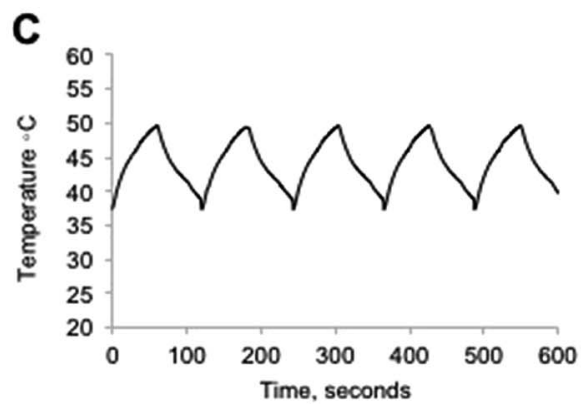

Fig. 3 Effect of in vitro laser irradiation of HNPs $\left(5 \mu \mathrm{g} \mathrm{mL}^{-1} \& 50 \mu \mathrm{g} \mathrm{mL}^{-1}\right)$ in BxPC-3 cells determined by (A) thermal rise at irradiation point and (B) heat dissipation away from laser focal point measured using a thermal imaging camera $(n=3 \pm$ SD) and (C) temperature of irradiation point over multiple irradiation cycles. 
maximum possible heating temperature for this concentration may not have been reached within the 60 second period and hence no plateau observed.

The effect of multiple irradiation cycles on the heating of HNPs was evaluated using cycles of 60 seconds irradiation followed by 60 seconds rest. This pattern was repeated over 5 cycles to a total of 600 seconds (10 minutes). The heating pattern shown in Fig. 3C shows that the heat generation from laser irradiation using these HNPs was consistent with identical heating and cooling profiles across the timeframe. This indicated that the heat generation did not result in any adverse effects such as damage to the structural integrity of the particles as this undoubtedly would have resulted in a shift in the heating profile.

\subsection{Measurement of HSP27 \& HSP70 production after laser irradiation}

It is important if HNPs are to progress further into clinical applications, that the effect they induce on cells after irradiation is understood. The HNPs themselves have shown no significant toxicity or impairment to the membrane integrity at the two concentrations over the time period being tested $\left(5 \mu \mathrm{g} \mathrm{mL}{ }^{-1} \&\right.$ $50 \mu \mathrm{g} \mathrm{mL}{ }^{-1}$ ) as shown in Fig. 2. For application as theranostics or drug carriers in cancer therapy, the heat induced by the HNPs can be harnessed for either tumour ablation, or as a drug release stimuli or indeed a dual platform for both. In this case, it is important to identify how these short sharp irradiations may impact on the cellular state. Hence the production of heat shock proteins (HSPs) was monitored. HSPs are upregulated in response to stress such as temperature changes and exposure to UV radiation. Cells produce HSPs to try and protect themselves from any irreversible damage arising from the stress factor, ${ }^{27}$ however some studies have suggested that HSPs may aid chemotherapies by acting as chaperones to ensure the drugs reach their desired site in the cell. ${ }^{28}$

For pancreatic adenocarcinoma it is reported that the main HSPs produced after the cells experience thermal increase are HSP27 and HSP70. The measurement of HSP27 with and without irradiation was compared with control cells without irradiation (Fig. 4A). Control cells with no particles were also irradiated with no deviation in temperature or heat shock protein production. The data suggested that the cells incubated with $5 \mu \mathrm{g} \mathrm{mL}{ }^{-1}$ HNPs did not result in any significant increase in HSP27 production after $24 \mathrm{~h}(p>0.01)$. This was not unexpected as the $\Delta T$ profile at this concentration did not show any notable thermal rise after irradiation. However, at $50 \mu \mathrm{g} \mathrm{mL}$ the cells which had been irradiated showed an increase in HSP27 production up to $130 \%$ compared with the cells experiencing no irradiation $(p<0.01)$.

Similarly the ELISA for measuring HSP70 (Fig. 4B) showed no significant increase in HSP70 after irradiation with $5 \mu \mathrm{g} \mathrm{mL}$ HNPS but $135 \%$ production was observed at $50 \mu \mathrm{g} \mathrm{mL} \mathrm{m}^{-1}(p<$ $0.01)$. These findings show that whilst the total irradiation time of the cells was only 60 seconds and the $\Delta T$ was a relatively modest $9{ }^{\circ} \mathrm{C}$ compared with previous phantom studies, this was still enough to induce cellular stress.
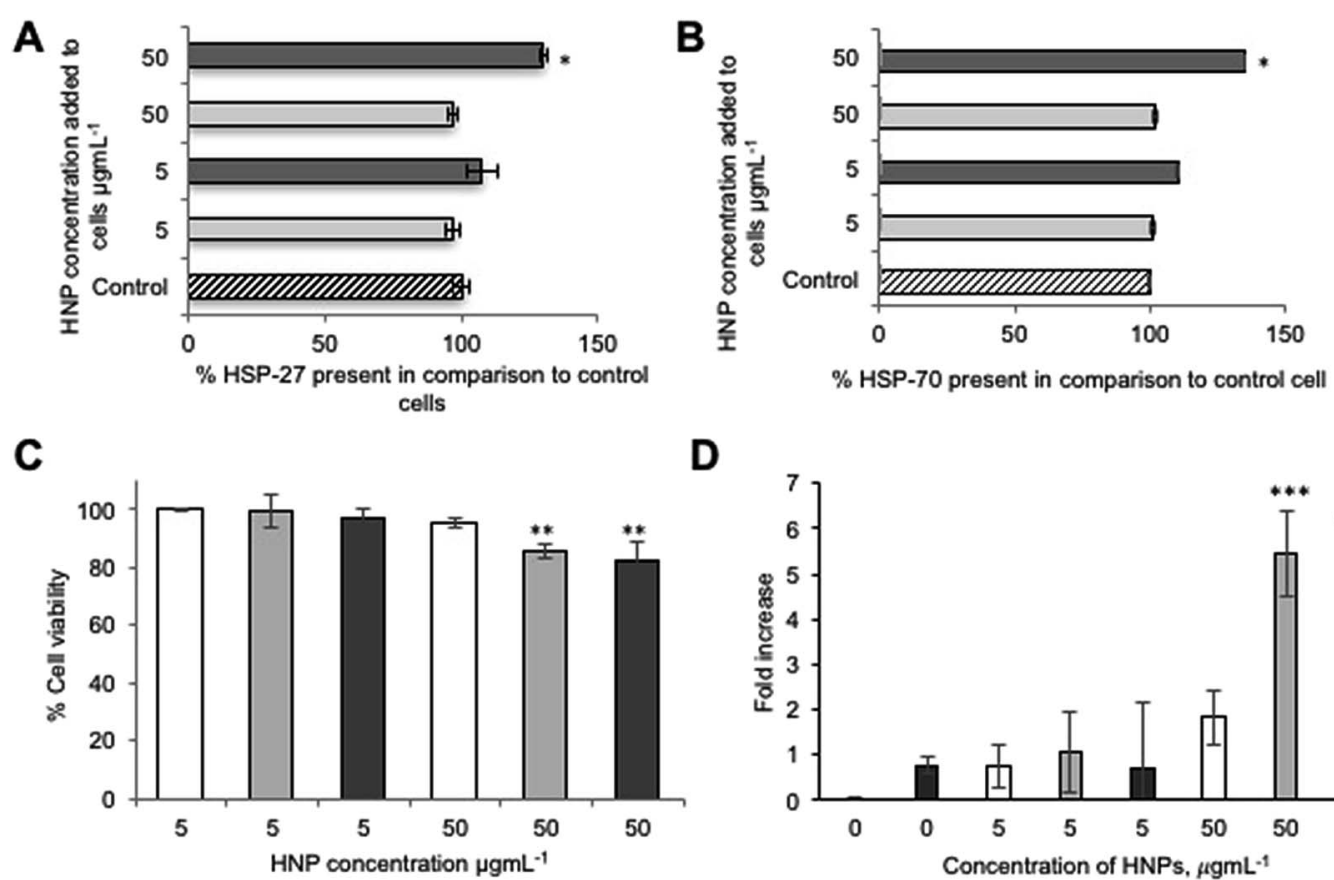

D

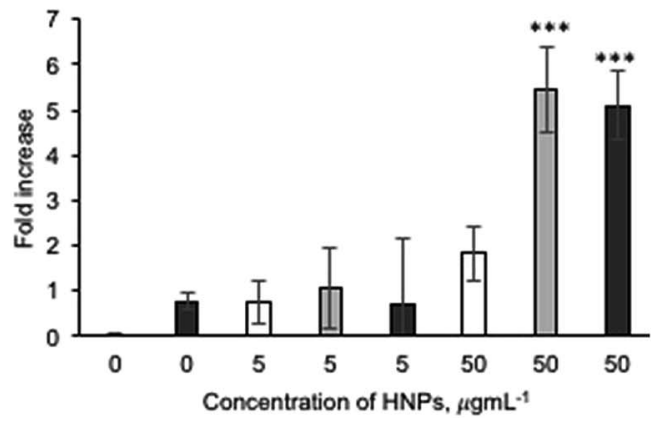

Fig. 4 Cellular response after laser irradiation of HNPs $\left(5 \mu \mathrm{g} \mathrm{mL}^{-1} \& 50 \mu \mathrm{g} \mathrm{mL}^{-1}\right)$ in BxPC-3 cells determined by ELISA measurement of heat shock protein production (A) HSP27 and (B) HSP70 $24 \mathrm{~h}$ post 60 second irradiation. (C) measurement of cell viability using trypan blue exclusion and (D) apoptosis detection via caspase-3 enzymatic activity measurement $24 \mathrm{~h}$ post 60 second and multiple $\mathbf{\square}$ irradiation cycles $(n=3 \pm$ SD) ( $\square$ cells incubated with HNPs experiencing no laser irradiation). * denotes significant increase in HSP production compared to control cells, ** denotes significant reduction in viability compared with control sample, *** denotes significant increase in caspase-3 activity compared with control cells $(p<0.01)$. 


\subsection{Cell viability after laser irradiation}

The cell viability was measured $24 \mathrm{~h}$ after laser irradiation of cells incubated with $5 \mu \mathrm{g} \mathrm{mL}{ }^{-1} \& 50 \mu \mathrm{g} \mathrm{mL}{ }^{-1}$ HNPS in order to determine if the heat produced resulted in adverse effects resulting in cell death. Fig. $4 \mathrm{C}$ shows the \% viability of the treated cells with and without laser irradiation compared with untreated control cells. Here the data is in line with the HSP production. Whereby, at $5 \mu \mathrm{g} \mathrm{mL} \mathrm{m}^{-1} \mathrm{HNP}$ incubation and irradiation, no adverse effect was observed on cell viability. However, a small reduction in viability after 60 seconds laser irradiation was observed at $50 \mu \mathrm{g} \mathrm{mL}^{-1} \mathrm{HNP}$ incubation and irradiation with $85 \%$ of cells being viable after the $24 \mathrm{~h}$ period $(p<0.01)$. Interestingly, the cells did not experience any major reduction in cell viability after multiple irradiation cycles compared with the single irradiation samples. This indicates that the cells could be multiply irradiated with little effect to cells and that the temperature itself is the only contributing factor to the cellular fate and not the duration of the cycles. In the case of this study, therefore, the HSPs produced may be adequate enough to allow recovery of cells and hence ablation is not achieved.

\subsection{Detection of apoptosis via measurement of caspase-3 activity after laser irradiation}

Caspase-3 activity was measured as an indication of the apoptotic state of the cells (Fig. 4D). In line with the cell viability, those cells which underwent laser irradiation after incubation with $5 \mu \mathrm{g} \mathrm{mL}{ }^{-1}$ HNPs did not experience a significant increase in caspase- 3 activity. This indicated that the cells were in a healthy state and were not undergoing apoptosis. In contrast, those cells which were incubated with $50 \mu \mathrm{g} \mathrm{mL}^{-1}$ HNPs did possess significant caspase-3 activity with a $5 \%$ increase compared with the controls. These findings were in agreement with the heat shock protein production at higher HNP concentrations after laser ablation. In common with the cytotoxicity, the caspase-3 levels did not increase with increasing irradiation cycles, and hence it can be further confirmed that the temperature alone was sufficient to initiate
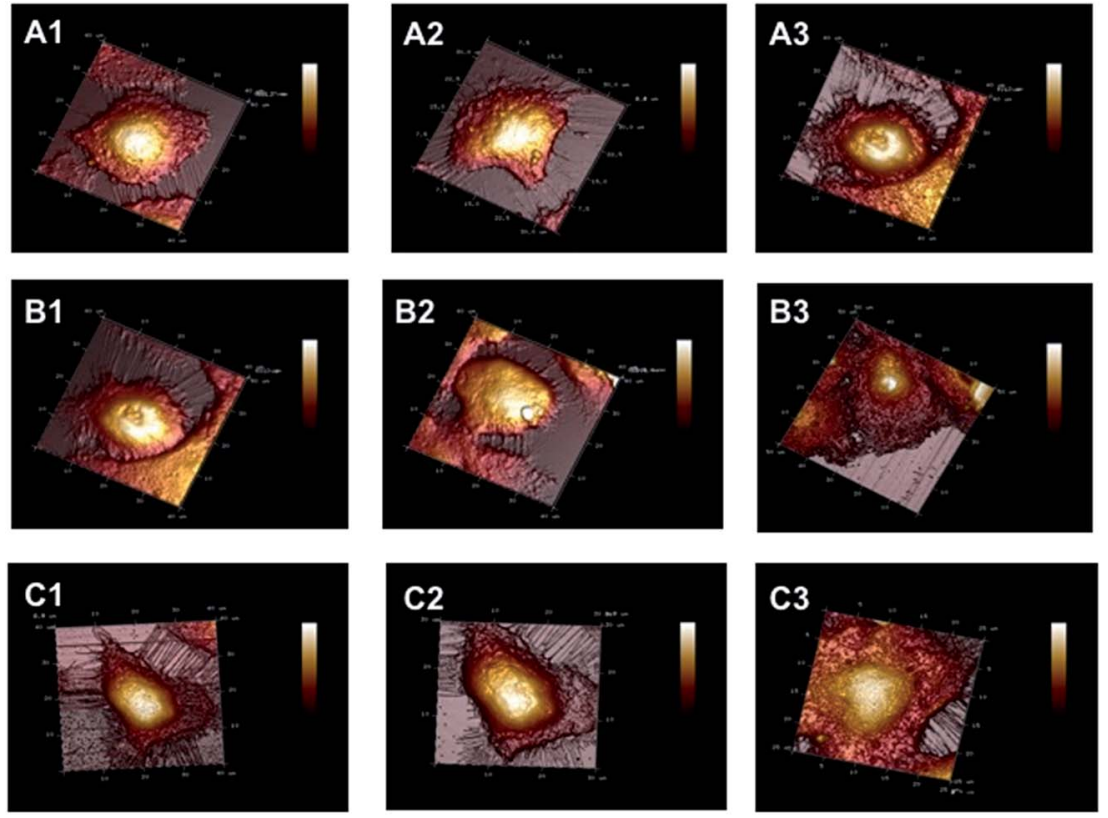

D

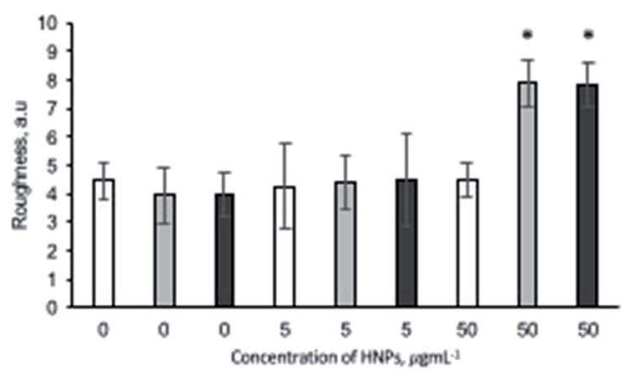

Fig. 5 Effect of HNP irradiation on BxPC-3 cell topography measured using atomic force microscopy. Topography imaged in (1) control cells, (2) cells incubated with $5 \mu \mathrm{g} \mathrm{mL}{ }^{-1}$ HNPs \& (3) cells incubated with $50 \mu \mathrm{g} \mathrm{mL}^{-1} \mathrm{HNPs}$ both (A) untreated and (B) irradiated for 60 seconds and (C) after multiple irradiation cycles. Cells were fixed $24 \mathrm{~h}$ post irradiation and imaged using Scan Asyst Adaptive Mode. (D) Roughness analysis carried out from topography images and analysed using NanoScope Analysis software ( $n=3 \pm \mathrm{SE}$ ). $\square$ cells experiencing no irradiation, $\mathbf{\square} 60$ seconds irradiation, and $\mathbf{D}$ multiple irradiation cycles. * denotes a significant increase compared to control cells $(p<0.01)$. 
the changes to cellular state and not necessarily the duration of irradiation.

\subsection{Imaging of cellular topography after laser irradiation using atomic force microscopy}

In order to further investigate the cellular response after laser irradiation of the HNPs the cellular topography was imaged using AFM (Fig. 5). Here the cells were fixed after $24 \mathrm{~h}$ post irradiation. The images showed (Fig. 5B2) that cellular morphology was not altered after 60 seconds laser irradiation of HNPs incubated at $5 \mu \mathrm{g} \mathrm{mL}{ }^{-1}$ compared with the control cells and those with HNPs without irradiation (Fig. 5A1 and B1 respectively). However, in comparison to the control cells (Fig. 5B3) the cells incubated with HNPs at $50 \mu \mathrm{g} \mathrm{mL}{ }^{-1}$ did have an effect on morphology. Here the cells appeared a little rougher and flatter compared to the control sample, and the cells incubated with HNPs without irradiation and (Fig. 5A1 and B1 respectively). Although the cell viability assays indicated only slight reduction in viability was observed, the AFM images indicate that the cells have undergone some alteration compared with their normal state as a consequence of laser irradiation of the internalised HNPs. However, this did not appear to be exacerbated further upon multiple irradiation cycles, with the cells (Fig. 5C3) looking similar to the single irradiation cells.
Cell roughness analysis was carried out on the topography images obtained. The data (Fig. 5D) indicated that the cells experiencing the laser irradiation with $50 \mu \mathrm{g} \mathrm{mL} \mathrm{m}^{-1}$ HNPs possessed significant increase in membrane roughness compared to the control cells, in agreement with the visual images.

\subsection{In situ measurement and imaging of tumour heating in pancreatic xenograft models}

The in vitro studies confirmed that once under physiological conditions and at concentrations which may be clinically relevant, the HNPs exhibited different thermal behavior to previous gel phantom studies. To further elucidate the heating potential inside biological systems the HNPs were irradiated after I.T. injection into subcutaneous xenograft pancreatic tumours, volume $=0.9 \mathrm{~cm}^{3}$ (Fig. 6A) immediately postmortem and imaged using the thermal camera. Fig. 6 shows the heating effect on the tumour tissue after 60 seconds irradiation. In the control mouse, no tissue heating effect was observed at the irradiation site (Fig. 6B1-3). In contrast the mouse with HNPs injected I.T. showed localized heated at the laser irradiation point which spread to the entire tumour over the 60 second period. Interestingly, the tumour tissue achieved $\Delta T$ of up to 10 ${ }^{\circ} \mathrm{C}$ which is an increase compared to the in vitro studies (although not significant $p>0.01$ ) (Fig. 6D1). However, the
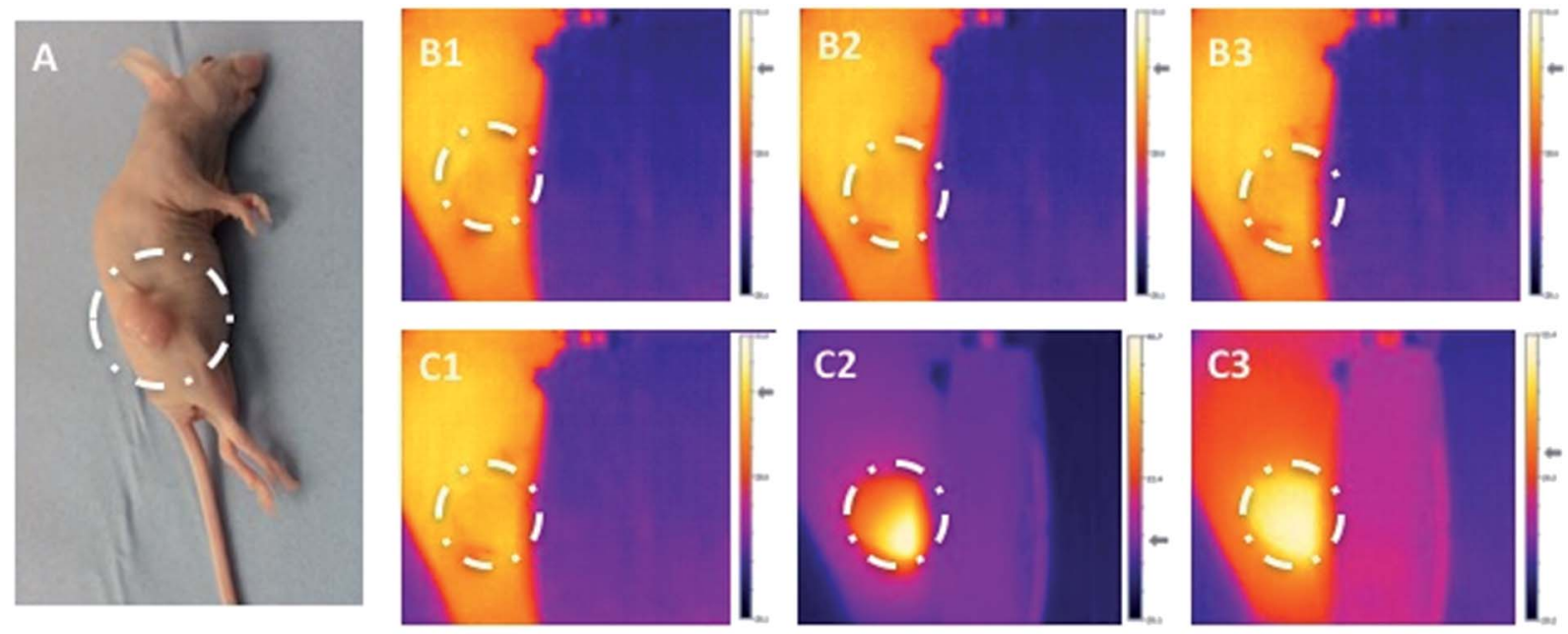

D1

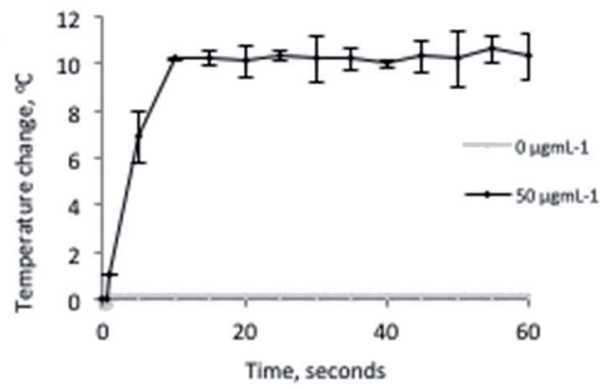

D2

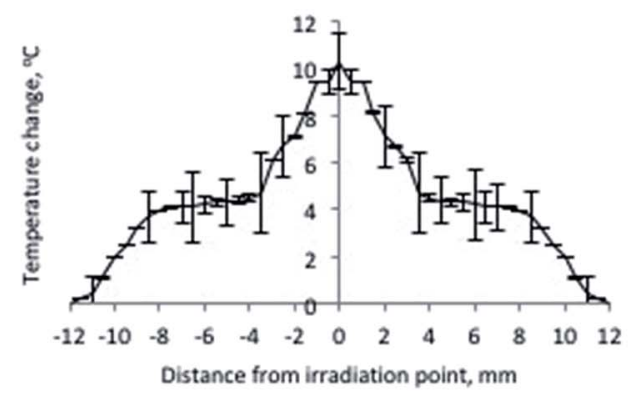

Fig. 6 Effect of in situ laser irradiation of HNPs injected I.T. in pancreatic xenograft models. (A) Nu/Nu xenograft (BxPC-3) tumor bearing mouse, (B \& C) heat dissipation maps of tumours absent (B) and with $50 \mu \mathrm{g} \mathrm{mL}^{-1} \mathrm{HNPs}$ I.T. (C) at (1) $t=0 \mathrm{~s}$, (2) $t=30 \mathrm{~s}$ and (3) $t=60 \mathrm{~s}$. (D) Quantification of (1) thermal rise at irradiation point and (2) heat dissipation away from laser focal point measured using a thermal imaging camera ( $n=3 \pm$ SD). 
heating profile was similar to the agar phantom studies, this perhaps indicated when the HNPs are in more confined areas that their thermal efficiency increases. The fascinating images show that the heat spread or dissipation is confined to the three dimensional tumour structure and does not appear to have dissipated through to the main anatomy of the mouse. In common with the in vitro studies (and contrast to the phantom studies) the HNP irradiation resulted in a thermal increase which could be detected up to $11 \mathrm{~mm}$ in each direction from the laser focal point - tumour measurements $(11.9 \mathrm{~mm} \times 11 \mathrm{~mm})$. This resulted in an irradiation area of $491 \mathrm{~mm}^{2}$ (Fig. 6D2). After irradiation, the tumours were re-measured to see whether heating of the HNPs had any effect on total tumour volume. This study showed that no difference in tumour volume was experienced after irradiation and that average tumour volume was $0.9 \mathrm{~cm}^{3}$. The relatively increased area experiencing heat dissipation compared to the agar samples indicates that these phantoms may act as indicators of heating potential, but do not indicate in vivo fate.

\section{Conclusion}

With the findings from this work it can be concluded that the HNPs are capable of acting as nano-heaters after laser irradiation at $1064 \mathrm{~nm}$ at $50 \mu \mathrm{g} \mathrm{mL} \mathrm{m}^{-1}$, which appeared to be an applicable concentration clinically as the particles were well tolerated by the cells. The lower concentration of $5 \mu \mathrm{g} \mathrm{mL} \mathrm{L}^{-1} \mathrm{did}$ not appear to be effective for nano-heating applications, probably because the particles were too far apart spatially in order for their gold shell heating to adequately cause any major increase in bulk temperature. The production of heat shock proteins in the $50 \mu \mathrm{g} \mathrm{mL} \mathrm{m}^{-1} \mathrm{HNP}$ irradiation sample indicated that the short duration of irradiation and spike in temperature was adequate to result in cellular stress and this must be taken into account when designing these particles for future application. In this study the cells were incubated at $37^{\circ} \mathrm{C}$ and a $\Delta T$ of $9{ }^{\circ} \mathrm{C}$ resulting in temperatures up to $46^{\circ} \mathrm{C}$. Indeed, there was a small effect on cell viability after irradiation, however, for application in tumour ablation either the irradiation period would need to be extended or the HNP concentration increased to induce a great enough stress on cells resulting in programmed cell death. This correlates with previous studies where they have stated that temperatures as high as $50{ }^{\circ} \mathrm{C}$ are required for irreversible cellular damage to occur. However, in vivo it has been reported that cancerous tissue exists at higher temperatures than normal body tissue with temperatures as high as $44{ }^{\circ} \mathrm{C}$, therefore, these HNPs may be sufficient in reaching temperatures of up to $53{ }^{\circ} \mathrm{C}$ causing ablation. However, this is yet to be explored. As such, it is suggested that the HNPs in this form (size, morphology, concentration) may be useful in theranostic systems whereby MRI guidance is inferred from the magnetic iron oxide core as well as the heat harnessed from laser irradiation for stimuli responsive drug release. It is postulated that the combined use of drug therapy and in vitro/in vivo heating will result in a synergistic effect resulting in a more efficient rate of kill. This work is currently being investigated.

\section{Conflict of interest}

The authors have declared that no competing interests exist.

\section{Acknowledgements}

This work was carried out and funded by the School of Pharmacy and the Institute for Science and Technology in Medicine, Faculty of Medicine and Health Sciences, Keele University. In vivo work was carried out in the School of Life Sciences, Faculty of Natural Sciences, Keele University.

\section{References}

1 A. Jemal, A. Thomas, T. Murray and M. Thun, Ca-Cancer J. Clin., 2002, 52, 23-47.

2 H. Igarashi, T. Ito, T. Hisano, N. Fujimori, Y. Niina, M. Yasuda, T. Kaku, S. Matsuo, T. Oono, M. Yoshinaga, H. Sakai and R. Takayanagi, Case Rep. Oncol., 2011, 4, 534541.

3 A. Sa Cunha, C. Rault, C. Laurent, X. Adhoute, V. Vendrely, G. Béllannée, R. Brunet, D. Collet and B. Masson, J. Am. Coll. Surg., 2005, 201, 359-365.

4 M. Malekigorji, A. D. M. Curtis and C. Hoskins, J. Nanomed. Res., 2014, 1, 1.

5 J. Wang, X. Zhang, Y. Cen, X. Lin and Q. Wu, Colloids Surf., B, 2016, 146, 707-715.

6 D. Ansari, B. Tingstedt, B. Andersson, F. Holmquist, C. Sturesson, C. Williamsson, A. Sasor, D. Borg, M. Bauden and R. Andersson, Future Oncol., 2016, 12, 1929-1946.

7 E. C. Dreaden, L. A. Austin, M. A. Mackey and M. A. El-Sayed, Ther. Delivery, 2012, 3, 457-478.

8 T. Sun, Y. S. Zhang, B. Pang, D. C. Hyun, M. Yang and Y. Xia, Angew. Chem., 2014, 53, 12321-12364.

9 T. Malarvizhi, M. Remya, M. Ashokumar, K. Muthukumaran, G. Anusha, M. N. Priyadharshni and A. Kiruba, International Journal of Innovative Research and Creative Technology, 2015, 1, 117-123.

10 K. Greish, Methods Mol. Biol., 2010, 624, 25-37.

11 K. Y. Choi, G. Liu, S. Lee and X. Chen, Nanoscale, 2012, 4, 330-342.

12 Z. Fan, P. P. Fu, H. Yu and P. C. Ray, J. Food Drug Anal., 2014, 22, 3-17.

13 C. M. Barnett, M. Gueorgieva, M. R. Lees, D. J. McGarvey and C. Hoskins, J. Nanopart. Res., 2013, 15, 1706.

14 C. M. Barnett, M. Gueorguieva, M. R. Lees, D. J. McGarvey, R. J. Darton and C. Hoskins, J. Nanopart. Res., 2012, 14, 1170.

15 A. J. Wagstaff, S. D. Brown, M. R. Holden, G. E. Craig, J. A. Plumb and R. E. Brown, Inorg. Chim. Acta, 2012, 393, 328-333.

16 X. Huang and M. A. El-Sayed, J. Adv. Res., 2010, 1, 13-28.

17 O. A. Yeshchenko, N. V. Kutsevol and A. P. Naumenko, Plasmonics, 2016, 11, 345-350.

18 S. Jain, D. G. Hirst and J. M. O'Sullivan, Br. J. Radiol., 2012, 85, 101-113. 
19 Y. Guo, Z. Zhang, D. Kim, W. Li, J. Nicolai, D. Procissi, Y. Huan, G. Han, R. R. Omary and A. C. Larson, Int. J. Nanomed., 2013, 8, 3437-3446.

20 A. Espinosa, R. D. Corato, J. Kolosnjaj-Tabi, P. Flaud, T. Pellegrino and C. Wilhelm, ACS Nano, 2016, 10, 24362446.

21 A. D. M. Curtis, M. Malekigorji, J. Holman, M. Skidmore and C. Hoskins, J. Nanomed. Nanotechnol., 2015, 6, 6.

22 S. K. Cheong, S. Krishnan and S. H. Cho, Med. Phys., 2012, 36, 4664-4671.
23 C. Hoskins, Y. Min, M. Gueorguieva, C. McDougall, A. Volovick, P. Prentice, Z. Wang, A. Melzer, A. Cuschieri and L. Wang, J. Nanobiotechnol., 2012, 10, 27.

24 A. M. Bannuah, D. Vllasaliu, J. Lord and S. Stolnik, Mol. Pharm., 2014, 11, 4363-4373.

25 N. Oh and J.-H. Park, Int. J. Nanomed., 2014, 9, 51-63.

26 L. Kou, J. Sun, Y. Zhai and Z. He, Asian J. Pharm. Sci., 2013, 8, 1-10.

27 S. Fulda, A. M. Gorman, O. Hori and A. Samali, Int. J. Cell Biol., 2010, 214074.

28 G. Jego, A. Hazoumé, R. Seigneuric and C. Garrido, Cancer Lett., 2013, 28, 275-285. 